\title{
The Evolving Role of Biomarkers in Personalized Lung Cancer Therapy
}

\author{
Janaki Sharma Elaine Shum Vincent Chau Daniel Paucar Haiying Cheng \\ Balazs Halmos \\ Departments of Medicine and Oncology, Montefiore Medical Center, Albert Einstein College of Medicine, Bronx, NY, USA
}

\begin{abstract}
Keywords
Non-small cell lung cancer · Targeted therapy · Molecular genetics · Personalized medicine - Immunotherapy ·

Circulating tumor DNA
\end{abstract}

\section{Introduction}

Globally, lung cancer has the highest mortality of all cancer sites amongst men and women [1]. Non-small cell lung cancer (NSCLC) represents $85-90 \%$ of all lung cancer diagnoses. Treatment options, until the last decade, were limited to curative intent surgery or radiation and traditional cytotoxic chemotherapy. With advanced disease, even first-line chemotherapy has minimal benefit. In the decade since this topic was last reviewed in Respiration, there have been dramatic research advances in the understanding of the underlying molecular mechanisms that lead to the development and progression of lung cancer [2]. Simultaneously, development of successful targeted agents directed against several of the key drivers of oncogenesis has changed the disease course for many patients (Table 1). More recently, the recognition of significant benefit from immune checkpoint inhibitor therapy led to another major transformational change in lung cancer management. Beginning with the most basic identifier of lung cancer - histology, and progressing to molecular alterations, immune system interactions and finally plasma markers, we will review the rapid multi- faceted evolution of biomarker-driven selection to optimally personalize lung cancer treatment as well as future research directions.

\section{Basic Histotypes of NSCLC}

Prior to the last decade, treatment for lung cancer was differentiated only by the main histological groups of small cell lung cancer (SCLC) and NSCLC. However, it is now known that differences in tumor histology affect response to chemotherapy and side effect profiles of certain agents. For example, during early clinical trials of the anti-VEGF monoclonal antibody (mAB) bevacizumab, a phase 2 study of carboplatin and paclitaxel plus or minus bevacizumab showed improved response rate, time to progression and overall survival (OS) with bevacizumab. However, the incidence of life-threatening pulmonary hemorrhage was $30 \%$ with squamous histology compared to $4 \%$ with adenocarcinoma [3]. Due to this unacceptable risk, further studies excluded squamous histology, and

Previous articles in this series: (1) Lange C, Siddiqui S: State-of-theart series on precision medicine in respiratory diseases. Respiration 2016;92:197-198. (2) Salzer HJF, Wassilew N, Köhler N, Olaru ID, Günther G, Herzmann C, Kalsdorf B, Sanchez-Carballo-P, Terhalle E, Rolling $T$, Lange $C$, Heyckendorf J: Personalized medicine for chronic respiratory infectious diseases: tuberculosis, nontuberculous mycobacterial pulmonary diseases, and chronic pulmonary aspergillosis. Respiration 2016;92:199-214.

\section{KARGER}

(c) 2016 S. Karger AG, Basel

E-Mail karger@karger.com

www.karger.com/res
Balazs Halmos, MD

Department of Oncology, Montefiore Medical Center

Albert Einstein College of Medicine

1695 Eastchester Road, Bronx, NY 10461 (USA)

E-Mail bahalmos@montefiore.org 
Table 1. FDA approved nonchemotherapy drugs for the treatment of lung cancer

\begin{tabular}{|c|c|c|c|c|}
\hline Class & Drug & $\begin{array}{l}\text { Year of } \\
\text { approval }\end{array}$ & Biomarker & Indication \\
\hline \multirow[t]{2}{*}{$\begin{array}{l}\text { Antiangiogenic } \\
\text { agents }\end{array}$} & Avastin (bevacizumab) & 2006 & None & $\begin{array}{l}\text { In combination with carboplatin/ } \\
\text { paclitaxel chemotherapy for first-line } \\
\text { treatment of advanced nonsquamous } \\
\text { NSCLC }\end{array}$ \\
\hline & Cyramza (ramucirumab) & 2014 & None & $\begin{array}{l}\text { In combination with docetaxel for } \\
\text { advanced NSCLC following failure of } \\
\text { platinum-based chemotherapy }\end{array}$ \\
\hline \multirow[t]{8}{*}{$\begin{array}{l}\text { Targeted drugs - } \\
\text { EGFR }\end{array}$} & Tarceva (erlotinib) & 2004 & None & $\begin{array}{l}\text { Following failure of at least } 1 \text { prior } \\
\text { chemotherapy }\end{array}$ \\
\hline & Tarceva (erlotinib) & 2010 & None & $\begin{array}{l}\text { For maintenance treatment of patients } \\
\text { with advanced NSCLC whose disease has } \\
\text { not progressed after four cycles of } \\
\text { platinum-based doublet chemotherapy }\end{array}$ \\
\hline & Tarceva (erlotinib) & 2013 & $\begin{array}{l}\text { Cobas EGFR mutation test; } \\
\text { Cobas v2 ctDNA EGFR } \\
\text { mutation testing (2016) }\end{array}$ & $\begin{array}{l}\text { First-line treatment of EGFR exon } 19 \\
\text { deletion or L858R mutation positive } \\
\text { advanced NSCLC }\end{array}$ \\
\hline & Gilotrif (afatinib) & 2013 & $\begin{array}{l}\text { Therascreen EGFR RGQ } \\
\text { PCR Kit; ctDNA EGFR } \\
\text { mutation testing }\end{array}$ & $\begin{array}{l}\text { First-line treatment of EGFR exon } 19 \\
\text { deletion or L858R mutant advanced } \\
\text { NSCLC }\end{array}$ \\
\hline & Iressa (gefitinib) & 2015 & $\begin{array}{l}\text { Therascreen EGFR RQG } \\
\text { OCR Kit; ctDNA EGFR } \\
\text { mutation testing }\end{array}$ & $\begin{array}{l}\text { First-line treatment of advanced EGFR } \\
\text { exon } 19 \text { deletion or L858R mutation } \\
\text { positive NSCLC }\end{array}$ \\
\hline & Tagrisso (osimertinib) & 2015 & Cobas EGFR mutation test v2 & Advanced EGFR T790M positive NSCLC \\
\hline & Portrazza (necitumumab) & 2015 & None & $\begin{array}{l}\text { First-line metastatic squamous cell lung } \\
\text { cancer in combination with cisplatin/ } \\
\text { gemcitabine chemotherapy }\end{array}$ \\
\hline & Gilotrif (afatinib) & 2016 & None & $\begin{array}{l}\text { Second-line treatment for metastatic } \\
\text { squamous cell carcinoma }\end{array}$ \\
\hline \multirow[t]{3}{*}{$\begin{array}{l}\text { Targeted drugs - } \\
\text { ALK }\end{array}$} & Xalkori (crizotinib) & 2011 & $\begin{array}{l}\text { ALK FISH positive (Vysis } \\
\text { ALK Break Apart FISH) }\end{array}$ & $\begin{array}{l}\text { ALK-positive locally advanced or } \\
\text { advanced NSCLC }\end{array}$ \\
\hline & Zykadia (ceritinib) & 2014 & ALK positive & $\begin{array}{l}\text { Crizotinib-refractory or intolerant } \\
\text { advanced ALK-positive NSCLC }\end{array}$ \\
\hline & Alecensa (alectenib) & 2015 & ALK positive & $\begin{array}{l}\text { Crizotinib-refractory or intolerant } \\
\text { advanced ALK-positive NSCLC }\end{array}$ \\
\hline $\begin{array}{l}\text { Targeted drugs - } \\
\text { ROS-1 }\end{array}$ & Xalkori (crizotinib) & 2016 & ROS1 positive & $\begin{array}{l}\text { Advanced ROS-1 gene alteration positive } \\
\text { NSCLC }\end{array}$ \\
\hline \multirow[t]{3}{*}{$\begin{array}{l}\text { Immunotherapeutic } \\
\text { agents }\end{array}$} & \multirow[t]{2}{*}{$\begin{array}{l}\text { Keytruda } \\
\text { (pembrolizumab) }\end{array}$} & 2015 & PD-L1 IHC 22C3 pharmDx & $\begin{array}{l}\text { Metastatic NSCLC following failure of } \\
\text { platinum-based chemotherapy, PD-L1 }\end{array}$ \\
\hline & & 2016 & Same & $\begin{array}{l}\text { positive (TPS } \geq 1 \% \text { ) } \\
\text { Metastatic NSCLC, EGFR/ALK-negative, } \\
\text { PD-L1 positive (TPS } \geq 50 \% \text { ) }\end{array}$ \\
\hline & Opdivo (nivolumab) & 2015 & $\begin{array}{l}\text { None mandated (PD-L1 IHC } \\
28-8 \text { pharmDx co-approved) }\end{array}$ & $\begin{array}{l}\text { Metastatic NSCLC following failure of } \\
\text { platinum-based chemotherapy }\end{array}$ \\
\hline
\end{tabular}

bevacizumab should only be used for the management of non-squamous NSCLC. Several years later, during phase 3 testing of the multitargeted antifolate pemetrexed in advanced NSCLC, it was discovered that pemetrexed plus cisplatin resulted in significantly improved OS for pa- tients with adenocarcinoma (12.6 vs. 10.9 months) and large-cell histology (10.4 vs. 6.7 months) compared to gemcitabine plus cisplatin. For patients with squamous cell histology, there was slightly improved OS with gemcitabine plus cisplatin (10.8 vs. 9.4 months) [4]. This his- 
tology dependence was noted in other studies as well and might possibly be related to differential expression of the main target of pemetrexed, thymidylate synthase in squamous versus non-squamous lung cancers. Consequently, pemetrexed is only approved and is widely used in the management of non-squamous NSCLC.

Recognizing the increasing importance of accurate histological subtyping for treatment and prognosis, the IASCLC, ATS, ERS (International Association for the Study of Lung Cancer, American Thoracic Society, European Respiratory Society) released new guidelines for the classification of lung adenocarcinoma. Specifically regarding small biopsy specimens or cytology, the guidelines recommend classification of NSCLC into adenocarcinoma or squamous cell by light microscopy and the minimum amount of special stains required to make the diagnosis in order to preserve more tissue for molecular testing. If the subtyping is truly uncertain, NSCLC NOS (not otherwise specified), the sample should be tested for molecular driver mutations, epidermal growth factor receptor (EGFR), and anaplastic lymphoma kinase (ALK), to give the patient the greatest options for treatment [5].

EGFR inhibitors have led to dramatic benefits for many patients with EGFR-activating mutations (mostly adenocarcinoma) and will be discussed further below. However, 2 EGFR-targeted drugs have shown improved benefit in patients with squamous cell NSCLC despite the lack of activating mutations or significant actual responses. Of note, similar benefits of EGFR-targeted therapy are well defined in squamous cell cancers of the head and neck region - both lung and head and neck squamous cell cancers demonstrate frequent and high level expression of EGFR and are molecularly also closely related. In the SQUIRE study, the anti-EGFR mAB necitumumab in combination with gemcitabine/cisplatin was found to improve OS by 1.6 months (11.5 vs. 9.9) over chemotherapy alone [6]. However, the INSPIRE study of necitumumab in combination with cisplatin/pemetrexed for non-squamous histology was closed early due to increased thromboembolic events and because it failed to demonstrate any improvement in survival [7]. Necitumumab received FDA approval in 2015 for use in conjunction with chemotherapy for treatment of advanced squamous NSCLC only. Also, more recently the irreversible pan-HER inhibitor, afatinib was also approved for the management of advanced squamous NSCLC based on positive results of the phase 3 LUX Lung- 8 study where treatment with afatinib versus erlotinib led to a significantly improved OS despite very low response rates in both arms of the study [8].

The Evolving Role of Biomarkers in Personalized Lung Cancer Therapy

\section{Molecular Targeted Therapy}

The identification of frequent key molecular alterations affecting driver oncogenes has revolutionized precision medicine for the treatment of lung cancer (Fig. 1). From the identification of targetable EGFR mutations to the intricacies of MET mutations, continued advancements have improved survival and quality of life for specific subsets of patients. For the most part, the known targetable mutations are mutually exclusive; although as the tumor evolves, it can acquire new mutations and lose old ones under the selection pressure of targeted agents.

\section{EGFR}

Activating mutations in the EGFR pathway lead to tumor growth, proliferation, invasion and metastasis. $\mathrm{Mu}-$ tations in this family result in constitutive activation of the tyrosine kinase domain and have been found with high frequency in lung adenocarcinomas, most commonly as deletions in exon 19 (Exon19del) and exon 21 (L858R). The frequency of EGFR mutations in lung cancer has been found to be higher in women, non-smokers, and can occur in up to $50 \%$ of Asian patients with lung adenocarcinoma with an average frequency of $10-15 \%$ in the US lung cancer population $[9,10]$.

Erlotinib and gefitinib are first-generation, oral EGFR tyrosine kinase inhibitors (TKIs) that have been approved for use as first-line therapy in patients with EGFR mutations. Initial studies showed very high, up to $60-80 \%$, response rates in tumors with EGFR mutations with frequently durable responses with progression-free survival (PFS) in the 6-10 months range. In 2012, a meta-analysis of 6 randomized controlled trials, including the IPASS trial comparing EGFR-targeted versus chemotherapy, found an improved overall response rate (ORR) and PFS in patients receiving a first-line EGFR TKI in advanced EGFR-mutated NSCLC as compared to conventional chemotherapy with these pivotal studies resulting in front-line recommendation of EGFR TKI therapy in biomarker-selected patients and the incorporation of frontline molecular testing as part of routine management [11]. The biomarker analysis in the IPASS trial also showed that the presence of the EGFR mutation was the best predictor of response [9].

Afatinib is an oral, second-generation pan-HER TKI which acts as an irreversible inhibitor of the EGFR kinase domain via binding to the $\mathrm{C} 797$ amino acid residue. Randomized studies of afatinib versus chemotherapy in the LUX-Lung 3 and LUX-Lung 6 trials have demonstrated improved ORR and PFS similar to first-generation inhib- 


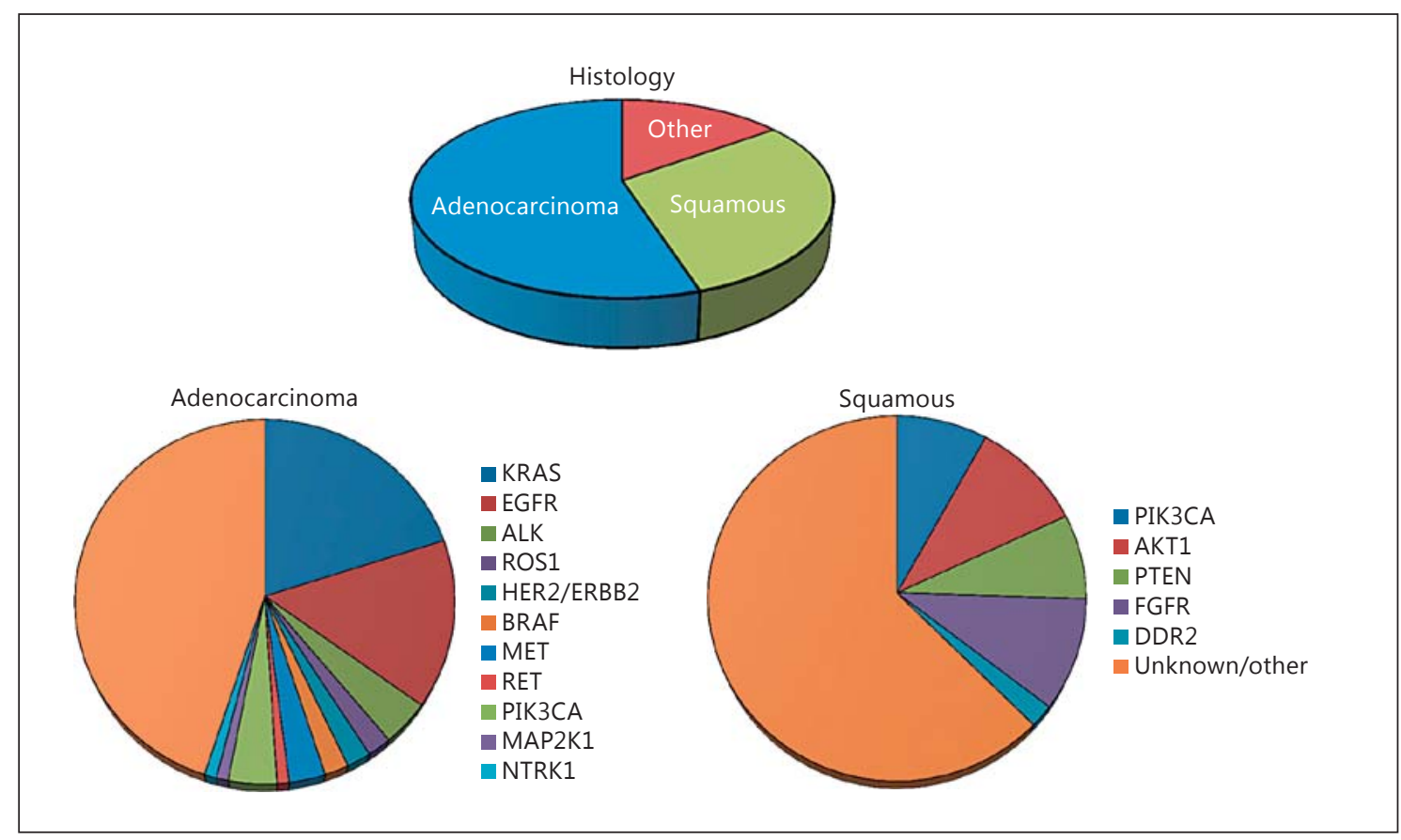

Fig. 1. Key molecular subsets of NSCLC. Adapted from Shaw et al. [19] and Caparica et al. [35].

itors and also suggested that EGFR exon 19 deletion-positive tumors may actually have better OS when treated with frontline afatinib as compared to chemotherapy. Conversely, patients with the L858R mutation appeared to have somewhat inferior outcome with afatinib [12].

\section{KRAS}

Mutations of the vi-Ki-ras2 Kirsten rat sarcoma (KRAS) gene affecting residues 12, 13, and 61 have been reported in approximately $20-30 \%$ of lung adenocarcinomas, predominantly in smokers; they are the most common driver oncogene alteration and are by and large mutually exclusive with other major oncogenic alterations, such as EGFR or ALK. The KRAS protein is a GTPase, and activity of the downstream signaling pathway including Raf-MEK-ERK is dependent on the conversion rate of GTP to GDP. Mutations in KRAS lead to constitutive activation of the RAS signaling pathway, associated with increased cell proliferation and reduced apoptosis [13].

Unlike the positive responses that have been seen with EGFR TKIs, targeted therapy against KRAS has been disappointing. This difficulty in KRAS targeting may be related to the KRAS protein's affinity for GTP/GDP and no known allosteric regulatory sites. Targeting downstream effectors of KRAS with a MEK inhibitor such as selu- metinib showed encouraging positive results in a randomized phase 2 trial of docetaxel +/- selumetinib; however, the confirmatory phase 3 study (SELECT-1) did not meet its primary endpoint of PFS and failed to have a significant effect on OS $[14,15]$. Novel ways of interfering with KRAS activity are being developed currently, and this remains an area of major unmet need in thoracic oncology.

\section{$A L K$}

In 2007, the fusion of the echinoderm microtubuleassociated protein-like 4 (EML4) and ALK was described to activate $A L K$ signaling. Later, a variety of fusions of ALK with other genes, most commonly EML4 leading to its dimerization and constitutive kinase activity were found to occur in $2-5 \%$ of lung adenocarcinomas. Activation of $A L K$ leads to activation of various targets including the RAS signaling pathway. Patients with ALK-translocated tumors are often younger in age, and are frequently light or never smokers [16].

The first approved agent targeting ALK, crizotinib, is an oral TKI of ALK, ROS1, and MET. The PROFILE 1007 trial compared the use of crizotinib to either docetaxel or pemetrexed in $A L K$-positive patients with locally advanced or metastatic NSCLC, and found an excellent 
ORR of $65 \%$ and improved PFS of 7.7 months with crizotinib compared to only 3 months with second-line chemotherapy alone [17]. The PROFILE 1014 trial examined the use of crizotinib in the first line setting and again found an improved ORR (75 vs. $45 \%$ ) and PFS (10.9 vs. 7 months) with crizotinib compared to chemotherapy [18]. Ceritinib and alectinib are second-generation ALK TKIs that are highly active in patients intolerant of or resistant to crizotinib $[19,20]$; both also have improved CNS penetrance, which is a significant benefit given the high frequency of CNS metastases in ALK-positive lung adenocarcinomas. A third agent, brigatinib, is currently seeking new drug approval from the FDA for treatment of crizotinib-resistant ALK-positive NSCLC based on positive data from a phase 2 study (ALTA) [21]. Studies comparing crizotinib with second-generation compounds are ongoing.

\section{ROS1}

The ROS1 gene is located on chromosome $6 \mathrm{q} 22$ and encodes a receptor tyrosine kinase belonging to the insulin receptor family. Chromosomal rearrangements can lead to the development of a ROS1 fusion protein with multiple protein partners similar to ALK [22]. The incidence of ROS1 rearrangements has been found almost exclusively in lung adenocarcinoma with a frequency of approximately $1-2 \%$ in several studies [22-25]. Similar to patients with ALK rearrangements, patients with ROS1 rearrangements tend to be younger and never smokers.

The use of crizotinib, which besides ALK also targets ROS and MET, to treat ROS-rearranged advanced NSCLC was reported in a phase 1 study with an objective response rate of $72 \%$ (95\% CI 58-84), a median duration of response of 17.6 months ( $95 \% 14.5$ to not reached), and a median PFS of 19.2 months (95\% 14.4 to not reached) [24]. A similar response rate was retrospectively reported from the EUROS1 cohort [25]. Given the rarity of this molecular subset, larger studies are not likely to be feasible, and the FDA recently indeed approved crizotinib for the management of ROS-positive NSCLC.

\section{MET}

Activation of the MET signaling pathway is involved in many oncogenic processes, such as epithelial-mesenchymal transition (EMT), invasion, and metastasis. Overexpression of the MET tyrosine kinase and its ligand hepatocyte growth factor (HGF) have been reported with high frequency in lung cancer; however, studies have shown that the level of MET expression does not necessarily correlate with response to MET inhibition, and pivotal phase 3 studies of Met-targeting agents such as with the MET-mAB and with the small molecule tivantinib failed to meet their primary endpoints $[26,27]$. More recently, multiple studies have identified recurrent and unique gene alterations in MET leading to skipping of translation of exon 14 which appears to define a subset of patients responsive to crizotinib [28-32]. The Cancer Genome Atlas (TCGA) and recent cohort studies have reported such $M E T$ exon 14 skipping alterations to occur in approximately $3-4 \%$ of NSCLC tumors of all subtypes with a significantly higher frequency in a rare and highly aggressive subtype called sarcomatoid carcinoma [30]. Reports of patients with these alterations treated by MET inhibitors, such as crizotinib and cabozantinib have thus far been limited to case reports and small case series, but the excellent responses noted already led to the adoption of testing for MET exon 14 mutations and treatment recommendations with MET inhibitors by the NCCN guideline [33]. The biological basis of the oncogenicity of this alteration might be mediated by decreased MET degradation due to loss of a critical C-Cbl binding site. In addition, high-level MET amplification might also define tumor subsets with responsiveness to MET inhibition.

\section{Other Mutations (RET, B-Raf, HER2, NTRK)}

Expanded use of high-throughput sequencing continues to identify additional driver mutations in lung cancer. Fusions of the RET gene are found in 1-2\% of NSCLCs and are more frequently found in never smokers. Early data have been reported in RET fusion-positive NSCLCs with partial responses to RET inhibition with cabozantinib [34].

B-Raf mutations lead to constitutive activation of the MAPK pathway, which is involved in cell growth and proliferation. In NSCLC, B-Raf mutations have been detected in $1-2 \%$ of patients. They are almost exclusively found in adenocarcinoma, and more commonly in smokers [35]. While up to $50 \%$ of B-Raf mutations in NSCLC are V600 mutations and may be responsive to B-Raf inhibitors such as vemurafenib [36], the other half are nonV600 mutations and have varying response to B-Raf inhibitors, but may be susceptible to MEK inhibitors. Continued studies to target B-Raf in NSCLC are underway, and high response rates have been noted with combinations of B-Raf and MEK inhibitors similar to what has been noted in patients with B-Raf-mutated malignant melanoma [37]. 
Table 2. Resistance to targeted therapies

\begin{tabular}{ll}
\hline Resistance mechanism & Key examples \\
\hline Development of secondary mutations & EGFR T790M; ALK L1196M \\
Gene copy number/amplification & $M E T, A L K$ \\
Activation of bypass pathways & $M E T$ amplification in EGFR; EGFR activation in ALK-mutated \\
& patients \\
Histologic transformation & EMT in EGFR-mutated patients, small cell transformation \\
Pharmacodynamic resistance & CNS disease after use of agents that do not penetrate the \\
& blood-brain barrier (e.g. crizotinib)
\end{tabular}

EMT, epithelial to mesenchymal transition.

Recurrent alterations of another HER family member, ErbB2, such as the YVMA insertion in exon 20, extracellular mutations and gene amplification have been noted in a small fraction of NSCLC, although the actionability of these alterations remains unclear. The use of antiErbB2 antibodies, such as trastuzumab and pertuzumab and small molecule TKIs, such as afatinib and neratinib continue to be studied in HER2-mutated NSCLC [38].

The neurotrophic receptor tyrosine kinase 1 (NTRK1) gene encodes the TRKA protein, a high-affinity nerve growth factor receptor. Fusion alterations have been identified in $0.1-3 \%$ of NSCLC patients in different studies. Entrectenib is a multikinase ALK/ROS1/NTRK1 inhibitor that has shown significant antitumor activity in one patient with stage 4 lung adenocarcinoma and an SQSTM-NTRK fusion mutation enrolled in a phase 1 trial $[39,40]$.

While readily actionable subsets are yet to emerge in patients with squamous cell lung cancers, recurrent alterations of the FGFR, PI3 kinase pathway, and others have been noted [41] and are the focus of large basket trials, such as the key Lung-MAP study [42].

\section{Resistance to Targeted Therapies}

Another key development in the field of lung cancer management has been in the area of acquired resistance to targeted agents, such as EGFR/ALK inhibitors (Table 2). While many molecularly selected patients initially show excellent responses to these agents, most patients on EGFR TKIs eventually have progression of their disease after a median of 9-12 months [10]. Of note, studies have shown that this resistance may be partial, and discontinuing these TKIs may lead to rapid progression of disease called a flare phenomenon [43]. Re-biopsy and sequencing of patients with progression of disease while on an EGFR TKI as well as in vitro and mouse studies led to the discovery of a multitude of potential resistance mechanisms. The most common and best validated resistance mechanism to EGFR TKIs is through a second site mutation, T790M in exon 20. This mutation occurs in $50-60 \%$ of patients and enhances the affinity of the ATP binding pocket for ATP, leading to competitive inhibition of the EGFR TKIs while also leading to steric hindrance to first-generation inhibitors leading to high level resistance [44]. While initial efforts at developing irreversible EGFR inhibitors, such as afatinib met with limited success due to a narrow therapeutic window, more recently specific T790M-targeting EGFR inhibitors have been successfully identified and demonstrate great success in the clinic. The lead compound of its class, osimertinib was recently approved by the FDA for patients with T790M-positive disease and progression after an EGFR TKI [21, 45]. Brigatinib (discussed above) also has activity in T790M-positive disease [21].

Patients with progression while on a first-generation EGFR TKI are recommended to have re-biopsy of their disease to potentially detect a T790M mutation and studies are now ongoing to compare first and third generation EGFR inhibitors in front-line management. As these new agents require irreversible binding to the C797 amino acid residue for full activity, it might not be too surprising that mutations of this residue (C797S) have emerged as one key new resistance mechanism in recent studies [46].

Additional genetic alterations have also been associated with acquired resistance. The best validated is MET gene amplification which occurs in approximately 5-20\% of patients with EGFR TKI resistance and acts independently through enhanced bypass signaling requiring coinhibition of both EGFR and MET in such cases [47, 48]. MET amplification may drive ErbB3-dependent activa- 
tion of PI3K independent of EGFR activity. Similar bypass mechanisms have been postulated for several other tyrosine kinases, such as ErbB2 and AXL $[49,50]$.

Mechanisms of acquired resistance have been identified at numerous other levels. At a histological level, the EMT is a process in which organized epithelial cells transform to resemble disorganized mesenchymal cells, and changes suggestive of an EMT transition have been found in tumor cells associated with resistance to EGFR TKIs. These cells lose their epithelial cell junction proteins, such as e-cadherin, and gain mesenchymal markers such as vimentin and N-cadherin [51]. Mesenchymal cells are invasive and may be resistant to EGFR TKIs due to their intrinsic lack of sensitivity to the downregulation of intracellular signaling pathways, and this EMT transition might overlap with MET/AXL activation. Histological transformation of NSCLC to SCLC has also been described in patients resistant to EGFR TKIs. Sequist et al. [52] found that $14 \%$ of patients in their cohort demonstrated this transformation, and later studies suggested that this might be secondary to loss of RB [53]. As these small cell cancers retain the activating EGFR mutation, such a small cell transformation suggests the possible presence of cancer stem cells capable of multilineage differentiation in contributing to resistance. As small cell transformation can respond to chemotherapy regimens for SCLC, re-biopsies to document this are of key importance.

For $A L K$-positive lung cancers, acquired resistance to crizotinib is attributed to several factors. A spectrum of mutations within the ALK kinase domain have been found, most commonly a gatekeeper mutation in L1196M that prevents steric binding and a C1156Y mutation that increases catalytic kinase activity. Particularly in ALKpositive tumors, the high incidence of CNS involvement presents as an example of pharmacodynamic mechanism of resistance as crizotinib does not penetrate the bloodbrain barrier well [17]. Alterations in other genes and bypass pathways have also been reported, but so far treatment responsiveness has not been correlating well with such alterations. The 2 recently approved, second-generation agents, ceritinib and alectinib, as well as brigatinib (pending approval), appear to have significant activity in both patients with and without secondary ALK mutations and also have excellent CNS penetration [21, 54, 55]. Understanding as to resistance mechanisms against firstand second-generation agents is rapidly growing and defines the G1202R mutation as one that is resistant to a broad-spectrum of agents with activity noted in nextgeneration ALK inhibitors such as lorlatinib [56].

The Evolving Role of Biomarkers in Personalized Lung Cancer Therapy

\section{Clonal Heterogeneity and Mutation Burden}

Recent studies have brought to light key issues regarding tumor heterogeneity and clonal evolution. Development of cancer has been described as part of an evolutionary process by following Darwinian concepts of survival [57]. Each tumor may consist of a group of subclones with varying driver and/or passenger mutations complicating our approach to targeted therapy. The development of clonal evolution in response to either intrinsic characteristic changes of the tumor or in response to extrinsic factors such as application of EGFR TKIs may contribute to the development of drug resistance. Gerlinger et al. [58] described this intratumor heterogeneity in renal cell carcinomas, proposing that a biopsy of a single tumor may underestimate the majority of genetic aberrations, and possible therapeutic targets, present in the malignancy. In contrast, Zhang et al. [59] used multiregion whole-exome sequencing on 11 localized lung adenocarcinomas and found all to have intratumor heterogeneity, but they were able to identify $76 \%$ of all mutations in all regions of the individual tumors. The authors suggested that the degree of intratumor heterogeneity may vary amongst cancer types, and that perhaps single-region sequencing may be adequate in lung adenocarcinomas. Preexisting tumor heterogeneity might imply the ab ovo presence of some resistance mechanism, e.g. EGFR T790M that can then just simply emerge due to clonal dominance over drugsensitive clones [60]. Alternatively, high mutation rates in lung cancer cells might allow the acquisition of novel mutations on therapy as well leading to an alternative path to the emergence of resistance, and the overall biological behavior of a tumor might be predetermined based on the initial heterogeneity of tumors at the outset of therapy, tumor geography, and pharmacological barriers. Improved understanding of such evolutionary processes promises the development of successful combination strategies to prevent the emergence of resistance.

With the advent of NGS technology, the clinical significance of the overall mutation burden as a reflection of neoantigen diversity in addition to specific mutations has also been explored. Xiao et al. [61] found that in lung adenocarcinoma, a greater mutation burden, defined as more than 4 total genetic alterations using ultra-deep targeted sequencing, was correlated with poorer OS. Govindan et al. [62] compared the mutational burden between smokers and never smokers, and found a much higher number of point mutations in tumors from smokers, which correlates with findings from other groups [63]. The therapeutic implications of mutational burden are 
still being explored. One study of NSCLC patients treated with pembrolizumab used whole-exome sequencing to correlate mutational burden with response to treatment. In patients with high nonsynonymous mutation burden (defined as greater than the median of the cohort, 209 mutations), 73\% experienced durable clinical benefit versus only $13 \%$ of patients with low mutation burden (below the median). ORR and PFS were also both higher in patients with high mutation burden. Higher levels of neoantigens, which occur in the setting of increased somatic mutations, might explain why immunotherapy is more effective with greater mutation burden and are analogous to the significant differences noted in the efficacy of immunotherapy in colorectal cancers with or without microsatellite instability [64]. These findings might explain the lesser activity of immunotherapy noted in EGFR/ ALK-positive NSCLCs where mutation burden is in general 10-fold lower than smoking-related lung cancers [65].

\section{Immune System-Tumor Cell Interactions}

Over the last several years, immunotherapy has come to the forefront of research in NSCLC and has completely transformed the treatment landscape. Recently, agents targeting the immune checkpoint, specifically the programmed death 1 receptor (PD-1)/programmed death ligand 1 (PD-L1) axis, have shown significant activity in patients with advanced NSCLC and given improved OS as compared to second-line chemotherapy; both pembrolizumab and nivolumab have been approved for the second-line treatment of advanced NSCLC. Checkpoints are one of the immune system's key innate mechanisms to modulate $\mathrm{T}$ cell response and avoid excessive inflammation. Interactions between receptors and ligands on $\mathrm{T}$ cells and the antigen-presenting cell or tumor cell send co-stimulatory or co-inhibitory signals. The PD-L1 and PD-1 are one such inhibitory pair that can be upregulated in NSCLC leading to immune resistance. Nivolumab, a $\mathrm{mAB}$ targeting PD-1, was the first immune checkpoint inhibitor to be approved in NSCLC. In patients with both advanced squamous and non-squamous histology NSCLC, compared to docetaxel, nivolumab demonstrated improved OS, PFS, and response rate with fewer side effects $[66,67]$. While in squamous cell histology membrane expression of PD-L1 as evaluated via a validated, commercially available IHC kit was not correlated with response to nivolumab, in non-squamous histology PDL1 expression and OS were positively correlated. Pem- brolizumab, another $\mathrm{mAB}$ targeting $\mathrm{PD}-1$, also demonstrated good ORR (19.4\%) and OS (12 months) in patients with advanced PD-L1-positive (defined as PD-L1+ in more than $50 \%$ cells) NSCLC in a phase 1 study leading to FDA approval for patients with positive PD-L1 expression [68] and the pivotal phase 3 Keynote-010 study had demonstrated an OS benefit over second-line docetaxel in a broad range of PD-L1+ (defined as more than 1\%) disease. In this case, PD-L1 expression evaluated with a different proprietary antibody and IHC assay demonstrated increasing benefit with the highest benefit in patients with PD-L1 expression in greater than $50 \%$ of tumor cells [69]. Although not yet approved, atezolizumab, an $\mathrm{mAB}$ targeting PD-L1, demonstrated similarly significant improvement in OS compared to docetaxel in a randomized phase 2 study [70]. OS benefit was strongly correlated with PD-L1 expression as assessed by IHC both on tumor cells and tumor-infiltrating immune cell.

While results with targeting of the PD-1 pathway have been revolutionary, unlike selecting patients for EGFR and ALK inhibitors, we do not have a very powerful predictive biomarker yet to aid in treatment selection. PD-L1 expression appears to correlate with response to treatment in many studies; however, even patients without PD-L1 tumor expression by IHC show response to treatment with PD-1/PD-L1-targeted agents and outcomes equal that with second-line chemotherapy, thereby making biomarker selection not mandatory for treatment selection [66, 67]. Some of the inconsistencies between studies might be related to the different assays that were used in studies for each of the above agents and no standardization of positive values within the assay or amongst different assays is available yet; however, several efforts are under way to accomplish this. Even at the level of the individual patient, $\mathrm{PD}-\mathrm{L} 1$ assays are fraught with difficulties as detection/expression of PD-L1 varies within the tumor as well as over time [71]. At this time, PD-L1 is not a consistent or reliable predictive biomarker to exclude patients from checkpoint inhibitor treatment; however, it can be used to predict the degree of treatment responsiveness and potentially to identify patients for more aggressive therapy, such as PD-L1-negative patients for combination strategies $[72,73]$. In fact, recent dramatic results of the Keynote-024 study demonstrating significantly improved outcomes, including prolongation of OS with upfront pembrolizumab versus doublet platinum-based chemotherapy in patients with PD-L1 high positive (TPS score $>50 \%$ ) argue for the rapid incorporation of PD-L1 testing for advanced NSCLC patients for upfront immunotherapy [74]. 


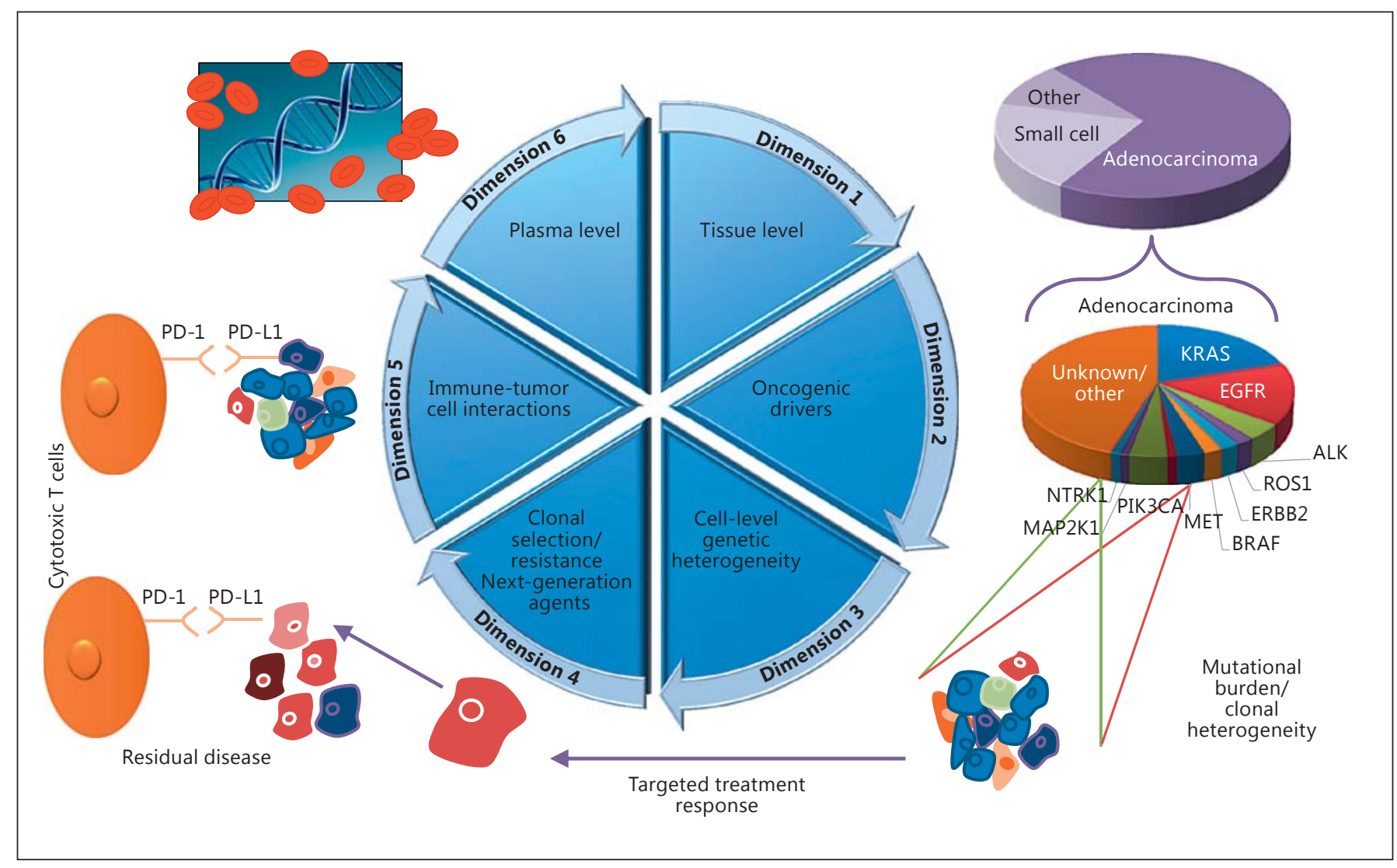

Fig. 2. The multidimensional context of biomarker testing for lung cancer treatment selection.

\section{Plasma as a Reflection of Intratumoral Molecular Dynamics and Immune Response}

As outlined in prior sections, treatment selection of patients for targeted therapies and immunotherapies are more and more relying on ongoing assessment of tumor genetics as well as immune response to tumor. The majority of currently available tests rely on tumor biopsy samples with significant tissue needs that are difficult to meet with image-guided or endoscopic biopsies and fine needle aspirations which also carry significant risks and are inconvenient. Furthermore, repeat biopsies at progression of disease are an undesirable burden for most patients and many times are just not feasible due to the location of tumor. Fortunately, remarkable advances in plasma-based assays now generate tremendous hope for a sea of change as to the ability of non-invasive and dynamic monitoring of molecular and immunological changes.

Serum marker profiling is based on the recognition that tumor cells, parts of tumor cells and very specifically tu-
Table 3. Comparison of tissue- versus plasma-based testing for recurrence

\begin{tabular}{lll}
\hline Barriers to use & Tissue & $\begin{array}{l}\text { Plasma-based } \\
\text { ctDNA }\end{array}$ \\
\hline Patient willingness & $\times$ & \\
$\begin{array}{l}\text { Procedural risk/contraindication } \\
\text { Tumor heterogeneity }\end{array}$ & $\times$ & \\
ctDNA shedding & $\times$ & \\
Cost & $\times$ & $\times$ \\
Turnaround time & $\times$ & \\
Limited information & & $\times$ \\
\hline
\end{tabular}

mor DNA from apoptotic tumor cells routinely find their way into the bloodstream. Initial studies mostly focused on the detection of circulating tumor cells; currently, due to the rare nature of such cells and technological challenges, this platform appears less promising. On the other hand, with advances in next-generation sequencing and digital 


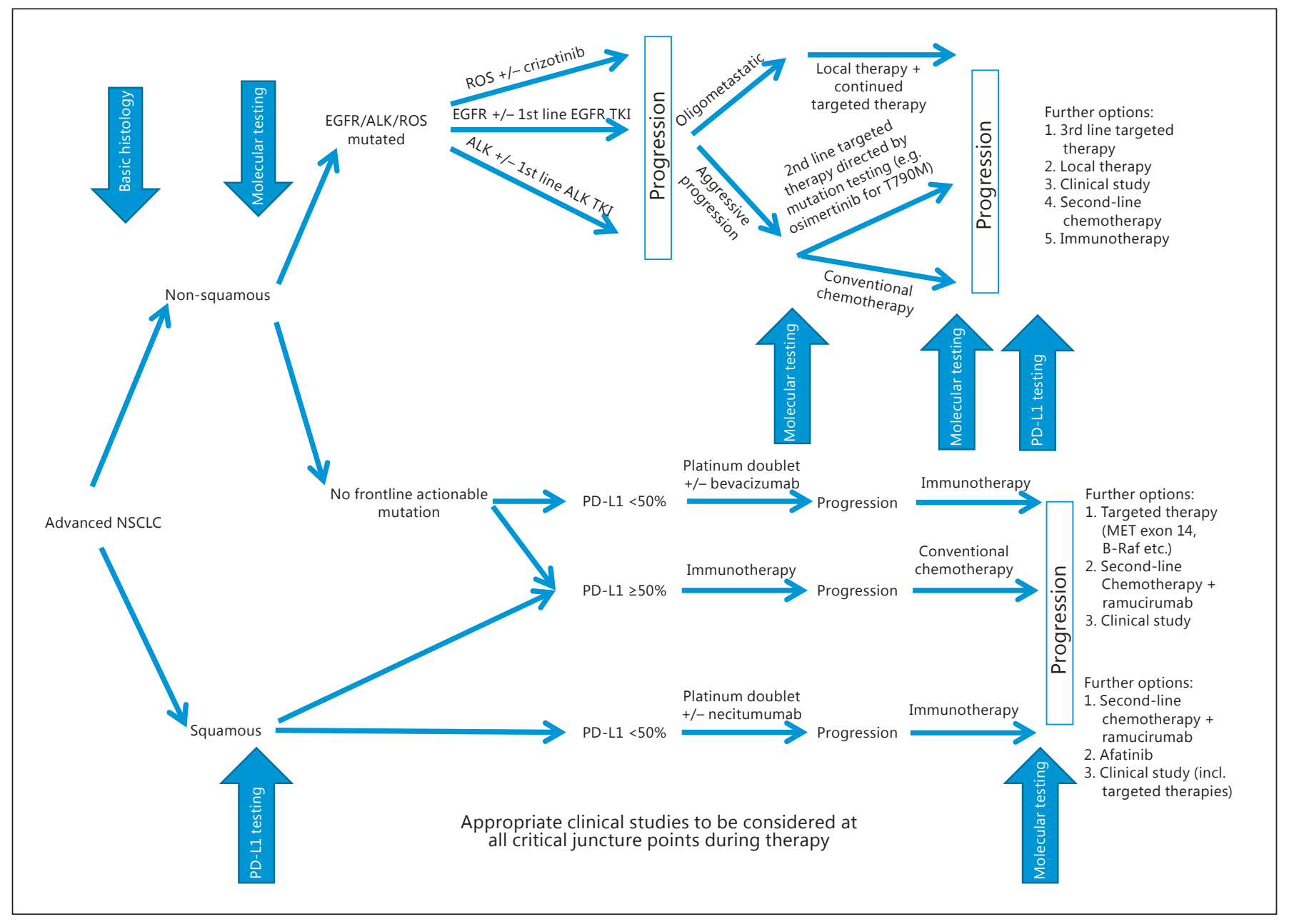

Fig. 3. Flowchart for management of advanced NSCLC.

PCR, researchers are now able to characterize circulating tumor DNA at levels as low as $0.1 \%$ of total blood DNA [75]. This technology has tremendous potential for several applications and has already been validated as a clinically useful way for the detection of the common EGFR T790M resistance mutation. Plasma ctDNA positivity appears to have as good a positive predictive value as tissuebased testing for determining in a non-invasive manner whether a patient could benefit from T790-targeted therapy [76]. Specifically, the presence of the T790M EGFR mutation has an excellent positive concordance with tissue testing [77, 78]. Admittedly, 100\% overlap between tissueand plasma-based testing is not anticipated as not all tumors "shed" ctDNA, and tissue-based testing on the other hand cannot provide the more "general" information from all tumor sites that ctDNA allows. In addition, as ctDNA approaches cannot detect some key resistance mechanisms, such as small cell transformation, the two are complimentary approaches at present (Table 3). A similar approach has also been extended to detecting T790M mutations in urine [79]. The next phase in ctDNA testing in addition to dynamic monitoring for resistance, is in primary mutation testing where several platforms demonstrate great promise, but further validation is needed still outside of the context of EGFR ctDNA mutation testing which gained recent FDA approval for treatment selection with erlotinib. Furthermore, ctDNA testing offers hope for monitoring of tumor recurrence as well as tumor response to both targeted and immunotherapeutic drugs. Lastly, immune-sequencing and peripheral blood T-cell repertoire studies might assist in optimization of immunotherapy approaches and neo-antigen discovery. 


\section{Conclusion}

The landscape for treatment of NSCLC has undergone a sea of change over the past decade due in large part to advances in molecular technology. Identification and understanding of the molecular mechanisms behind lung cancer development and resistance to treatment have been accompanied by development of new agents targeting oncogenic drivers and their respective resistance pathways (Fig. 2). Given the small number of patients harboring each of these targetable mutations, large clinical trials remain a significant hurdle to new treatments. However, trials like Lung-MAP seek to overcome these restrictions by directing patients to different therapeutic arms based on the results of molecular profiling. On another dimension, immune-targeted approaches are providing survival benefits to many patients without a targetable mutation, are entering the first-line treatment space based on PD-L1 selection, and will likely further improve with refinement of appropriate and replicable biomarkers. Although advanced NSCLC still confers a poor prognosis for most patients, greater personalization of treatment via selective use of biomarkers and targeted therapies is expected to expand and improve survival for more patients (Fig. 3).

\section{References}

1 Siegel RL, Miller KD, Jemal A: Cancer statistics, 2015. CA Cancer J Clin 2015;65:5-29.

-2 Breuer RHJ, Postmus PE, Smit EF: Molecular pathology of non-small-cell lung cancer. Respiration 2005;72:313-330.

-3 Johnson DH, Fehrenbacher L, Novotny WF, Herbst RS, Nemunaitis JJ, Jablons DM, Langer CJ, DeVore RF 3rd, Gaudreault J, Damico LA, Homgren E, Kabbinavar F: Randomized phase II trial comparing bevacizumab plus carboplatin and paclitaxel with carboplatin and paclitaxel alone in previously untreated locally advanced or metastatic nonsmall-cell lung cancer. J Clin Oncol 2004;22: 2184-2191.

4 Scagliotti GV, Parikh P, von Pawel J, Biesma B, Vansteenkiste J, Manegold C, Serwatowski P, Gatzemeier U, Diguamrti R, Zukin M, Lee JS, Mellemgaard A, Park K, Patil S, Rolski J, Goksel T, de Marinis F, Simms L, Sugarman KP, Gandara D: Phase III study comparing cisplatin plus gemcitabine with cisplatin plus pemetrexed in chemotherapy-naive patients with advanced-stage non-small-cell lung cancer. J Clin Oncol 2008;26:3543-3551.

5 Travis WD, Branbilla E, Noguchi M, et al: International Association for the Study of Lung Cancer/American Thoracic Society/European Respiratory Society international multidisciplinary classification of lung adenocarcinoma. J Thorac Oncol 2011;6:244-285.

6 6 Thatcher N, Hirsch FR, Luft AV, Szczesna A, Ciuleanu TE, Dediu M, Ramlau R, Galiulin RK, Bálint B, Losonczy G, Kazarnowicz A, Park K, Schumann C, Reck M, Depenbrock H, Nanda S, Kruljac-Letunic A, Kurek R, PazAres L, Socinski MA: Necitumumab plus gemcitabine and cisplatin versus gemcitabine and cisplatin alone as first-line therapy in patients with stage IV squamous non-small-cell lung cancer (SQUIRE): an open-label, randomised, controlled phase 3 trial. Lancet Oncol 2015;16:763-774.
7 Paz-Ares L, Mezger J, Ciuleanu TE, Fischer JR, von Pawel J, Provencio M, Kazarnowicz A, Losonczy G, de Castro G Jr, Szczesna A, Crino L, Reck M, Ramlau R, Ulsperger E, Schumann C, Miziara JE, Lessa ÁE, Dediu M, Bálint B, Depenbrock H, Soldatenkova V, Kurek R, Hirsch FR, Thatcher N, Socinski MA: Randomized phase 3 trial (INSPIRE) of necitumumab plus cisplatin-pemetrexed versus cisplatin-pemetrexed alone as first-line therapy in stage IV non-squamous NSCLC. J Thorac Oncol 2013;8:S139-S140.

-8 Soria JC, Felip E, Cobo M, Lu S, Syrigos K, Lee KH, Göker E, Georgoulias V, Li W, Isla D, Guclu SZ, Morabito A, Min YJ, Ardizzoni A, Gadgeel SM, Wang B, Chand VK, Goss GD: Afatinib versus erlotinib as second-line treatment of patients with advanced squamous cell carcinoma of the lung (LUX-Lung 8): an open-label randomized controlled phase 3 trial. Lancet Oncol 2015;16:897-907.

-9 Mok TS, Wu YL, Thongprasert S, Yang CH, Chu DT, Saijo N, Sunpaweravong P, Han B, Margono B, Ichinose Y, Nishiwaki Y, Ohe Y, Yang JJ, Chewaskulyong B, Jiang H, Duffield EL, Watkins CL, Armour AA, Fukuoka M: Gefitinib or carboplatin-paclitaxel in pulmonary adenocarcinoma. N Engl J Med 2009; 361:947-957.

$\checkmark 10$ Riely GJ, Yu HA: EGFR: the paradigm of an oncogene-driven lung cancer. Clin Cancer Res 2015;21:2221-2226.

11 Gao G, Ren S, Li A, Xu J, Xu Q, Su C, Guo J, Deng Q, Zhou C: Epidermal growth factor receptor-tyrosine kinase inhibitor therapy is effective as first-line treatment of advanced non-small-cell lung cancer with mutated EGFR: a meta-analysis from six phase III randomized controlled trials. Int J Cancer 2012; 131:E822-E829.
12 Yang JC, Wu YL, Schuler M, Sebastian M, Popat S, Yamamoto N, Zhou C, Hu CP, O’Byrne K, Feng J, Lu S, Huang Y, Geater SL, Lee KY, Tsai CM, Gorbunova V, Hirsh V, Bennouna J, Orlov S, Mok T, Boyer M, Su WC, Lee KH, Kato T, Massey D, Shahidi M, Zazulina V, Sequist LV: Afatinib versus cisplatin-based chemotherapy for EGFR mutation-positive lung adenocarcinoma (LUXLung 3 and LUX-Lung 6): analysis of overall survival data from two randomised, phase 3 trials. Lancet Oncol 2015;16:141-151.

13 Wood K, Hensing T, Malik R, Salgia R: Prognostic and predictive value in KRAS in nonsmall-cell lung cancer: a review. JAMA Oncol 2016;2:805-812.

-14 Jänne PA, Shaw AT, Pereira JR, Jeannin G, Vansteenkiste J, Barrios C, Franke FA, Grinsted L, Zazulina V, Smith P, Smith I, Crinò L: Selumetinib plus docetaxel for KRAS-mutant advanced non-small-cell lung cancer: a randomised, multicentre, placebo-controlled, phase 2 study. Lancet Oncol 2013;14:38-47.

15 Selumetinib did not meet trial endpoint of progression-free survival in KRASm NSCLC patients. Astra Zeneca Press Releases August 9, 2016. https://www.astrazeneca.com/mediacentre/press-releases/2016/AstraZeneca-provides-update-on-Phase-III-trial-of-Selumetinib-in-non-small-cell-lung-cancer-09082016. html (accessed October 3, 2016).

16 Castellanos EH, Horn L: Re-evaluating progression in an era of progress: a review of firstand second-line treatment options in anaplastic lymphoma kinase-positive non-small cell lung cancer. Oncologist 2016;21:755-761.

-17 Shaw AT, Kim DW, Nakagawa K, Seto T, Crino L, Ahn MJ, De Pas T, Besse B, Solomon BJ, Blackhall F, Wu YL, Thomas M, O’Byrne KJ, Moro-Sibilot D, Camidge DR, Mok T, Hirsh V, Riely GJ, Iyer S, Tassell V, Polli A, Wilner $\mathrm{KD}$, Janne PA: Crizotinib versus chemotherapy in advanced ALK-positive lung cancer. N Engl J Med 2013;368:2385-2394.
The Evolving Role of Biomarkers in Personalized Lung Cancer Therapy 
-18 Solomon BJ, Mok T, Kim DW, Wu YL, Nakagawa K, Mekhail T, Felip E, Cappuzzo F, Paolini J, Usari T, Iyer S, Reisman A, Wilner KD, Tursi J, Blackhall F: First-line crizotinib versus chemotherapy in ALK-positive lung cancer. N Engl J Med 2014;371:2167-2177.

19 Shaw AT, Kim DW, Mehra R, Tan DS, Felip E, Chow LQ, Camidge DR, Vansteenkiste J, Sharma S, De Pas T, Riely GJ, Solomon BJ, Wolf J, Thomas M, Schuler M, Liu G, Santoro A, Lau YY, Goldwasser M, Boral AL, Engelman JA: Ceritinib in ALK-rearranged nonsmall-cell lung cancer. N Engl J Med 2014; 370:1189-1197.

20 Ohe Y, Nishio M, Kiura K, Seto T, Nakagawa $\mathrm{K}$, Maemondo M, et al: A phase I/II study with a CNS-penetrant, selective ALK inhibitor alectinib in $A L K$-rearranged non-small cell lung cancer (ALK+ NSCLC) patients (pts): updates on progression free survival (PFS) and safety results from AF-001JP (abstract). J Clin Oncol 2015;33(suppl):8061.

21 Kim DW, Tiseo M, Ahn MJ, Reckamp KL, Hansen KH, Kim SW, Huber RM, West HJ, Groen HJM, Hochmair MJ, Leighl NM, Gettinger SN, Langer CJ, Paz-Ares LG, Smit EF, Kim ES, Reichmann WG, Kerstein D, Haluska FG, Camidge DR: Brigatinib (BRG) in patients (pts) with crizotinib (CRZ)-refractory ALK+ non-small cell lung cancer (NSCLC): first report of efficacy and safety from a pivotal randomized phase (ph) 2 trial (ALTA) (abstract). J Clin Oncol 2016;34(suppl):9007.

-22 Bergethon K, Shaw AT, Ou SH, Katayama R, Lovly CM, McDonald NT, Massion PP, Siwak-Tapp C, Gonzalez A, Fang R, Mark EJ, Batten JM, Chen H, Wilner KD, Kwak EL, Clark JW, Carbone DP, Ji H, Engelman JA, Mino-Kenudson M, Pao W, Iafrate AJ: ROS1 rearrangements define a unique molecular class of lung cancers. J Clin Oncol 2012;30: 863-870.

23 Cancer Genome Atlas Research Network: Comprehensive molecular profiling of lung adenocarcinoma. Nature 2014;511:543-550.

-24 Shaw AT, Ou SH, Bang YJ, Camidge DR, Solomon BJ, Salgia R, Riely GJ, Varella-Garcia M, Shapiro GI, Costa DB, Doebele RC, Le LP, Zheng Z, Tan W, Stephenson P, Shreeve SM, Tye LM, Christensen JG, Wilner KD, Clark JW, Iafrate AJ: Crizotinib in ROS1-rearranged non-small-cell lung cancer. N Engl J Med 2014;371:1963-1971.

25 Mazieres J, Zalcman G, Crino L, Biondani P, Barlesi F, Filleron T, Dingemans AM, Lena H, Monnet I, Rothschild SI, Cappuzzo F, Besse B, Thiberville L, Rouviere D, Dziadziuszko R, Smit EF, Wolf J, Spirig C, Pecuchet N, Leenders F, Heuckmann JM, Diebold J, Milia JD, Thomas RK, Gautschi O: Crizotinib therapy for advanced lung adenocarcinoma and a ROS1 rearrangement: results from the EUROS1 cohort. J Clin Oncol 2015;33:992-999.

-26 Rolfo C, Van der Steen N, Pauwels P, Cappuzzo F: Onartuzumab in lung cancer: the fall of Icarus? Expert Rev Anticancer Ther 2015; 15:487-489.
27 Scagliotti G, von Pawel J, Novello S, Ramlau R, Favaretto A, Barlesi F, Akerley W, Orlov S, Santoro A, Spigel D, Hirsh V, Shepherd FA, Sequist LV, Sandler A, Ross JS, Wang Q, von Roemeling R, Shuster D, Schwartz B: Phase III multinational, randomized, double-blind, placebo-controlled study of tivantinib (ARQ 197) plus erlotinib versus erlotinib alone in previously treated patients with locally advanced or metastatic non squamous nonsmall-cell lung cancer. J Clin Oncol 2015;33: 2667-2674.

28 Paik PK, Drilon A, Fan PD, Yu H, Rekhtman N, Ginsberg MS, Borsu L, Schultz N, Berger MF, Rudin CM, Ladanyi M: Response to MET inhibitors in patients with stage IV lung adenocarcinomas harboring MET mutations causing exon 14 skipping. Cancer Discov 2015;5:842-849.

29 Frampton GM, Ali SM, Rosenzweig M, Chmielecki J, Lu X, Bauer TM, Akimov M, Bufill JA, Lee C, Jentz D, Hoover R, Ou SH, Salgia R, Brennan T, Chalmers ZR, Jaeger S, Huang A, Elvin JA, Erlich R, Fichtenholtz A, Gowen KA, Greenbowe J, Johnson A, Khaira D, McMahon C, Sanford EM, Roels S, White J, Greshock J, Schlegel R, Lipson D, Yelensky R, Morosini D, Ross JS, Collisson E, Peters M, Stephens PJ, Miller VA: Activation of MET via diverse exon 14 splicing alterations occurs in multiple tumor types and confers clinical sensitivity to MET inhibitors. Cancer Discov 2015;5:850-859.

30 Liu X, Jia Y, Stoopler MB, Shen Y, Cheng H, Chen J, Mansukhani M, Koul S, Halmos B, Borczuk AC: Next-generation sequencing of pulmonary sarcomatoid carcinoma reveals high frequency of actionable MET gene mutations. J Clin Oncol 2016;34:794-802.

-31 Awad MM, Oxnard GR, Jackman DM, Savukoski DO, Hall D, Shivdasani P, Heng JC, Dahlberg SE, Janne PA, Verma S, Christensen J, Hammerman PS, Sholl LM: MET exon 14 mutations in non-small-cell lung cancer are associated with advanced age and stage-dependent met genomic amplification and cMet overexpression. J Clin Oncol 2016;34: 721-730.

32 Tong JH, Yeung SF, Chan AW, Chung LY, Chau SL, Lung RW, Tong CY, Chow C, Tin EK, Yu YH, Li H, Pan Y, Chak WP, Ng CS, Mok TS, To KF: MET amplification and exon 14 splice site mutation define unique molecular subgroups of non-small cell lung carcinoma with poor prognosis. Clin Cancer Res 2016;22:3048-3056.

33 Shum E, Halmos B: Skipping the line: bringing MET exon 14 skipping mutations to the forefront of targeted therapy. Transl Cancer Res 2016;5:110-116.

34 Drilon A, Wang L, Hasanovic A, Suehara Y, Lipson D, Stephens P, Ross J, Miller V, Ginsberg M, Zakowski MF, Kris MG, Ladanyi M, Rizvi N: Response to Cabozantinib in patients with RET fusion-positive lung adenocarcinomas. Cancer Discov 2013;3:630-635.
35 Caparica R, de Castro G Jr, Gil-Bazo I, Caglevic C, Calogero R, Giallombardo M, Santos ES, Raez LE, Rolfo C: BRAF mutations in non-small cell lung cancer: has finally Janus opened the door? Crit Rev Oncol Hematol 2016;101:32-39.

36 Hyman DM, Puzanov I, Subbiah V, Faris JE, Chau I, Blay JY, Wolf J, Raje NS, Diamond EL, Hollebecque A, Gervais R, Elez-Fernandez ME, Italiano A, Hofheinz RD, Hidalgo M, Chan E, Schuler M, Lasserre SF, Makrutzki M, Sirzen F, Veronese ML, Tabernero J, Baselga $\mathrm{J}$ : Vemurafenib in multiple nonmelanoma cancers with BRAF V600 mutations. N Engl J Med 2015;373:726-736.

37 Planchard D, Besse B, Groen HJ, Souquet PJ, Quoix E, Baik CS, Barlesi F, Kim TM, Mazieres J, Novello S, Rigas JR, Upalawanna A, D'Amelio AM, Zhang P, Mookerjee B, Johnson BE: Dabrafenib plus trametinib in patients with previously treated BRAF (V600E)mutant metastatic non-small cell lung cancer: an open-label, multicentre phase 2 trial. Lancet Oncol 2016;17:984-993.

-38 Mazieres J, Peters S, Lepage B, Cortot AB, Barlesi F, Beau-Faller M, Besse B, Blons $\mathrm{H}$, Mansuet-Lupo A, Urban T, Moro-Sibilot D, Dansin E, Chouaid C, Wislez M, Diebold J, Felip E, Rouquette I, Milia JD, Gautschi O: Lung cancer that harbors an HER2 mutation: epidemiologic characteristics and therapeutic perspectives. J Clin Oncol 2013;31:19972003.

39 Desai A, Menon SP, Dy GK: Alterations in genes other than EGFR/ALK/ROS1 in nonsmall cell lung cancer: trials and treatment options. Cancer Biol Med 2016;13:77-86.

40 Vaishanvi A, Capelletti M, Le AT, Butaney M, Ercan D, Mahale S, Davies KD, Aisner DL, Pilling AB, Berge EM, Kim J, Sasaki H, Park SI, Kryukov G, Garraway LA, Hammerman PS, Haas J, Andrews SW, Lipson D, Stephens PJ, Miller VA, Varella-Garcia M, Janne PA, Doebele RC: Oncogenic and drug-sensitive MTRK1 rearrangements in lung cancer. Nat Med 2013;19:1469-1471.

41 Cancer Genome Atlas Research Network: Comprehensive genomic characterization of squamous cell lung cancers. Nature 2012;489: 519-525.

42 Steuer CE, Papadimitrakopoulou V, Herbst RS, Redman MW, Hirsch FR, Mack PC, Ramalingam SS, Gandara DR: Innovative clinical trials: The LUNG-MAP Study. Clin Pharmacol Ther 2015;97:488-491.

43 Chaft JE, Oxnard GR, Sima CS, Kris MG, Miller VA, Riely GJ: Disease flare after tyrosine kinase inhibitor discontinuation in patients with EGFR-mutant lung cancer and acquired resistance to erlotinib and gefitinib: implications for clinical trial strategies. Clin Cancer Res 2011;17:6298-6303.

44 Kobayashi S, Boggon TJ, Dayaram T, Janne PA, Kocher O, Meyerson M, Johnson BE, Eck MJ, Tenen DG, Halmos B: EGFR mutation and resistance of non-small-cell lung cancer to gefitinib. N Engl J Med 2005;352:786-792. 
45 Janne PA, Yang JC, Kim DW, Planchard D, Ohe Y, Ramalingam SS, Ahn MJ, Kim SW, Su WC, Horn L, Haggstrom D, Felip E, Kim JH, Frewer P, Cantarini M, Brown KH, Dickinson PA, Ghiorghiu S, Ranson M: AZD9291 in EGFR inhibitor-resistant non-small-cell lung cancer. N Engl J Med 2015;372:1689-1699.

-46 See comment in PubMed Commons below Thress KS, Paweletz CP, Felip E, Cho BC, Stetson D, Dougherty B, Lai Z, Markovets A, Vivancos A, Kuang Y, Ercan D, Matthews SE, Cantarini M, Barrett JC, Janne PA, Oxnard GR: Acquired EGFR C797S mutation mediates resistance to AZD9291 in non-small cell lung cancer harboring EGFR T790M. Nat Med 2015;21:560-562.

- 47 Engelman JA, Zejnullahu K, Mitsudomi T, Song Y, Hyland C, Park JO, Lindeman N, Gale CM, Zhao X, Christensen J, Kosaka T, Holmes AJ, Rogers AM, Cappuzzo F, Mok T, Lee C, Johnson BE, Cantley LC, Janne PA: MET amplification leads to gefitinib resistance in lung cancer by activating ERBB3 signaling. Science 2007;316:1039-1043.

-48 Bean J, Brennan C, Shih JY, Riely G, Viale A, Wang L, Chitale D, Motoi N, Szoke J, Broderick S, Balak M, Chang WC, Yu CJ, Gazdar A, Pass H, Rusch V, Gerald W, Huang SF, Yang PC, Miller V, Ladanyi M, Yang CH, Pao W: MET amplification occurs with or without T790M mutations in EGFR mutant lung tumors with acquired resistance to gefitinib or erlotinib. Proc Natl Acad Sci USA 2007;104: 20932-20937.

-49 Zhang Z, Lee JC, Lin L, Olivas V, Au V, LaFramboise T, Abdel-Rahman M, Wang X, Levine AD, Rho JK, Choi YJ, Choi CM, Kim SW, Jang SJ, Park YS, Kim WS, Lee DH, Lee JS, Miller VA, Arcila M, Ladanyi M, Moonsamy P, Sawyers C, Boggon TJ, Ma PC, Costa C, Taron M, Rosell R, Halmos B, Bivona TG: Activation of the AXL kinase causes resistance to EGFR-targeted therapy in lung cancer. Nat Genet 2012;44:852-860.

50 Takezawa K, Pirazzoli V, Arcila ME, Nebhan CA, Song X, de Stanchina E, Ohashi K, Janjigian YY, Spitzler PJ, Melnick MA, Riely GJ, Kris MG, Miller VA, Ladanyi M, Politi K, Pao W: HER2 amplification: a potential mechanism of acquired resistance to EGFR inhibition in EGFR-mutant lung cancers that lack the second-site EGFR T790M mutation. Cancer Discov 2012;2:922-933.

-51 Suda K, Tomizawa K, Fujii M, Murakami H, Osada H, Maehara Y, Yatabe Y, Sekido Y, Mitsudomi T: Epithelial to mesenchymal transition in an epidermal growth factor receptor-mutant lung cancer cell line with acquired resistance to erlotinib. J Thorac Oncol 2011;6:1152-1161.

The Evolving Role of Biomarkers in Personalized Lung Cancer Therapy
52 Sequist LV, Waltman BA, Dias-Santagata D, Digumarthy S, Turke AB, Fidias P, Bergethon K, Shaw AT, Gettinger S, Cosper AK, Akhavanfard S, Heist RS, Temel J, Christensen JG, Wain JC, Lynch TJ, Vernovsky K, Mark EJ, Lanuti M, Iafrate AJ, Mino-Kenudson M, Engelman JA: Genotypic and histological evolution of lung cancers acquiring resistance to EGFR inhibitors. Sci Transl Med 2011;3: $75 \mathrm{ra} 26$.

53 Niederst MJ, Sequist LV, Poirier JT, Mermel C, Lockerman EL, Garcia AR, Katayama R, Costa C, Ross KN, Moran T, Howe E, Fulton LE, Mulvey HE, Bernardo LA, Monamoud F, Miyoshi N, VandeLaan PA, Costa DB, Janne PA, Border DR, Ramaswamy S, Shioda T, Iafrate AJ, Getz G, Rudin CM, Mino-Kenudson $\mathrm{M}$, Engelman JA: RB loss in resistant EGFR mutant lung adenocarcinomas that transform to small-cell lung cancer. Nat Commun 2015;11:6377.

$54 \mathrm{Ou} \mathrm{SH}$, Ahn JS, De Petris L, Govindan R, Yang JC, Hughes B, Lena H, Moro-Sibilot D, Bearz A, Ramirez SV, Mekhail T, Spira A, Bordogna W, Balas B, Morcos PN, Monnet A, Zeaiter A, Kim DW: Alectinib in crizotinibrefractory ALK-rearranged non-small-cell lung cancer: a phase II global study. J Clin Oncol 2016;34:661-668.

55 Shaw AT, Gandhi L, Gadgeel S, Riely GJ, Cetnar J, West H, Camidge DR, Socinski MA, Chiappori A, Mekhail T, Chao BH, Borghaei H, Gold KA, Zeaiter A, Bordogna W, Balas $\mathrm{B}$, Puig $\mathrm{O}$, Henschel V, Ou SH: Alectinib in ALK-positive, crizotinib-resistant, nonsmall-cell lung cancer: a single-group, multicentre, phase 2 trial. Lancet Oncol 2016;17: 234-242.

56 Gainor JF, Dardaei L, Yoda S, Friboulet L, Lescchiner I, Katayama R, Dagogo-Jack I, Gadgeel S, Schultz K, Singh M, Chin E, Parks M, Lee D, DiCecca RH, Lockerman E, Huynh T, Logan J, Ritterhouse LL, Le LP, Muniappan A, Digumarthy S, Channick C, Keyes C, Getz G, Dias-Santagata D, Heist RS, Lennerz J, Sequist LV, Benes $\mathrm{CH}$, Iafrate AJ, Mino-Knudsen M, Engelman JA, Shaw AT: Molecular mechanisms of resistance to first- and second-generation ALK inhibitors in ALK-rearranged lung cancer. Cancer Discov 2016;6: 1118-1133.

57 Greaves M, Maley CC: Clonal evolution in cancer. Nature 2012;481:306-313.

58 Gerlinger M, Rowan AJ, Horswell S, Larkin J, Endesfelder D, Gronroos E, Martinez P, Matthews N, Stewart A, Tarpey P, Varela I, Phillimore B, Begum S, McDonald NQ, Butler A, Jones D, Raine K, Latimer C, Santos CR, Nohadani M, Eklund AC, Spencer-Dene B, Clark G, Pickering L, Stamp G, Gore M, Szallasi Z, Downward J, Futreal PA, Swanton C: Intratumor heterogeneity and branched evolution revealed by multiregion sequencing. $\mathrm{N}$ Engl J Med 2012;366:883-892.
59 Zhang J, Fujimoto J, Zhang J, Wedge DC, Song X, Zhang J, Seth S, Chow CW, Cao Y, Gumbs C, Gold KA, Kalhor N, Little L, Mahadeshwar H, Moran C, Protopopov A, Sun $\mathrm{H}$, Tang J, Wu X, Ye Y, William WN, Lee JJ, Heymach JV, Hong WK, Swisher S, Wistuba II, Futreal PA: Intratumor heterogeneity in localized lung adenocarcinomas delineated by multiregion sequencing. Science 2014;346: 256-259.

60 Hata AN, Niederst MJ, Archibald HL, Gomez-Caraballo M, Siddiqui FM, Mulvey HE, Maruvka YE, Ji F, Bhang HE, Krishnamurthy Radhakrishna V, Siravegna G, Hu H, Raoof S, Lockerman E, Kalsy A, Lee D, Keating CL, Ruddy DA, Damon LJ, Crystal AS, Costa C, Piotrowska Z, Bardelli A, Iafrate AJ, Sadreyev RI, Stegmeier F, Getz G, Sequist LV, Faber AC, Engelman JA: Tumor cells can follow distinct evolutionary paths to become resistant to epidermal growth factor inhibition. Nat Med 2016:22;262-269.

61 Xiao D, Pan H, Li F, Wu K, Zhang X, He J: Analysis of ultra-deep targeted sequencing reveals mutation burden is associated with gender and clinical outcome in lung adenocarcinoma. Oncotarget 2016;7:22857-22864.

62 Govindan R, Ding L, Griffith M, Subramanian J, Dees ND, Kanchi KL, Maher CA, Fulton $\mathrm{R}$, Fulton L, Wallis J, Chen K, Walker J, McDonald S, Bose R, Ornitz D, Xiong D, You M, Dooling DJ, Watson M, Mardis ER, Wilson RK: Genomic landscape of non-small cell lung cancer in smokers and never-smokers. Cell 2012;150:1121-1134.

63 Ding L, Getz G, Wheeler DA, Mardis ER McLellan MD, et al: Somatic mutations affect key pathways in lung adenocarcinoma. Nature 2008;455:1069-1075.

64 Rizvi NA, Hellmann MD, Snyder A, Kvistborg P, Makarov V, Havel JJ, Lee W, Yuan J, Wong P, Ho TS, Miller ML, Rekhtman N, Moreira AL, Ibrahim F, Bruggeman C, Gasmi B, Zappasodi R, Maeda Y, Sander C, Garon EB, Merghoub T, Wolchok JD, Schumacher TN, Chan TA: Cancer immunology. Mutational landscape determines sensitivity to $\mathrm{PD}-1$ blockade in non-small cell lung cancer. Science 2015;348:124-128.

65 Gainor JF, Shaw AT, Sequist LV, Fu X, Azzoli CG, Piotrowska Z, Huynh TG, Zhao L, Fulton L, Schultz K, Howe E, Farago AF, Sullivan RJ, Stone JR, Digumarthy S, Moran T, Hata AN, Yagi Y, Yeap BY, Engelman JA, Mino-Kenudson M: EGFR mutations and ALK rearrangements are associated with low response rates to $\mathrm{PD}-1$ pathway blockade in non-small cell lung cancer: a retrospective analysis. Clin Cancer Res 2016;22:45854593. 
66 Brahmer J, Reckamp KL, Baas P, Crinò L, Eberhardt WE, Poddubskaya E, Antonia S, Pluzanski A, Vokes EE, Holgado E, Waterhouse D, Ready N, Gainor J, Arén Frontera O, Havel L, Steins M, Garassino MC, Aerts JG, Domine M, Paz-Ares L, Reck M, Baudelet C, Harbison CT, Lestini B, Spigel DR: Nivolumab versus docetaxel in advanced squamous cell non-small cell lung cancer. N Engl J Med 2015;373:123-135.

-67 Borghaei H, Paz-Ares L, Horn L, Spigel DR, Steins M, Ready NE, Chow LQ, Vokes EE, Felip E, Holgado E, Barlesi F, Kohlhäufl M, Arrieta $\mathrm{O}$, Burgio MA, Fayette J, Lena $\mathrm{H}$, Poddubskaya E, Gerber DE, Gettinger SN, Rudin CM, Rizvi N, Crinò L, Blumenschein GR Jr, Antonia SJ, Dorange C, Harbison CT, Graf Finckenstein F, Brahmer JR: Nivolumab versus docetaxel in advanced nonsquamous nonsmall-cell lung cancer. N Engl J Med 2015; 373:1627-1639.

68 Garon EB, Rizvi N, Hui R, Leighl N, Balmanoukian AS, Eder JP, Patnaik A, Aggarwal C, Gubens M, Horn L, Carcereny E, Ahn M, Felip E, Lee J, Hellmann MD, Hamid O, Goldman JW, Soria J, Dolled-Filhart M, Rutledge RZ, Zhang J, Lunceford JK, Rangwala R, Lubiniecki GM, Roach C, Emancipator K, Gandhi L: Pembrolizumab for the treatment of non-small-cell lung cancer. N Engl J Med 2015;372:2018-2028.
69 Herbst RS, Baas P, Kim DW, Felip E, PerezGarcia JL, Han JY, Molina J, Kim JH, Arvis CD, Ahn MJ, Majem M, Fidler MJ, de Castro G Jr, Garrido M, Lubiniecki GM, Shentu Y, Im E, Dolled-Filhart M, Garon EB: Pembrolizumab versus docetaxel for previously treated, PD-L1-positive, advanced non-small-cell lung cancer (KEYNOTE-010): a randomised controlled trial. Lancet 2016;387:1540-1550.

70 Fehrenbacher L, Spira A, Ballinger M, Kowanetz M, Vansteenkiste J, Mazieres J, Park K, Smith D, Artal-Cortes A, Lewanski C, Braiteh F, Waterkamp D, He P, Zou W, Chen DS, Yi J, Sandler A, Rittmeyer A: Atezolizumab versus docetaxel for patients with previously treated non-small-cell lung cancer (POPLAR): a multicentre, open-label, phase 2 randomised controlled trial. Lancet 2016;387:1837-1846.

71 McLaughlin J, Han G, Schalper KA, CarvajalHausdorf D, Pelekanou V, Rehman J, Velcheti V, Herbst R, LoRusso P, Rimm DL: Quantitative assessment of the heterogeneity of PD-L1 expression in non-small-cell lung cancer. JAMA Oncol 2016;2:46-54.

72 Lisberg A, Garon EB: The value of PD-L1 testing in non-small-cell lung cancer. JAMA Oncol 2016;2:571-572.

73 Pennell NA: PD-L1 testing and lack of benefit to guide treatment with immune checkpoint inhibitors in patients with non-small-cell lung cancer. JAMA Oncol 2016;2:569-570.
74 Reck M, Rodríguez-Abreu D, Robinson AG, Hui R, Csőszi T, Fülöp A, Gottfried M, Peled N, Tafreshi A, Cuffe S, O’Brien M, Rao S, Hotta K, Leiby MA, Lubiniecki GM, Shentu Y, Rangwala R, Brahmer JR; KEYNOTE-024 Investigators: Pembrolizumab versus chemotherapy for PD-L1-positive non-small-cell lung cancer. N Engl J Med 2016, Epub ahead of print.

75 Chi KR: The tumor trail left in blood. Nature 2016;532:269-271.

76 Sequist LV, Goldman JW, Wakelee HA, Camidge D, Yu H, Varga A: Efficacy of rociletinib (CO-1686) in plasma-genotyped T790M-positive NSCLC patients (abstract). J Clin Oncol 2015;33(suppl):8001.

77 Zhao X, Han RB, Zhao J, Wang J, Yang F, Zhong W, Zhang L, Li LY, Wang MZ: Comparison of epidermal growth factor receptor mutation statuses in tissue and plasma in stage I-IV non-small cell lung cancer patients. Respiration 2013;85:119-125.

78 Thress KS, Brant R, Carr TH, Dearden S, Jenkins S, Brown $\mathrm{H}$, Hammett T, Cantarini M, Barrett JC: EGFR mutation detection in ctDNA from NSCLC patient plasma: a crossplatform comparison of leading technologies to support the clinical development of AZD9291. Lung Cancer 2015;90:509-515.

79 Husain H, Kosco K, Vibat CRT, Melnikova V, Erlander MG, Cohen E, Lippman SM, Kuzrock R: Kinetic monitoring of EGFR T790M in urinary circulating tumor DNA to predict radiographic progression and response in $\mathrm{pa}-$ tients with metastatic lung adenocarcinoma. J Clin Oncol 2015;33(suppl):8081. 